\title{
18F-FDG PET/CT Imaging of Metastatic Testicular Choriocarcinoma Mimicking Gastric Cancer which Initial Symptom is Melena
}

\author{
Başlangıç Semptomu Melena Olan Mide Kanserini Taklit Eden Metastatik Testis \\ Koryokarsinomunun ${ }^{18}$ F-FDG PET/BT Görüntülemesi
}

\author{
I Recep Tayyip Erdoğan University Faculty of Medicine, Department of Nuclear Medicine, Rize, Turkey \\ 2Recep Tayyip Erdoğan University Faculty of Medicine, Department of Medical Oncology, Rize, Turkey \\ ${ }^{3}$ Recep Tayyip Erdoğan University Faculty of Medicine, Department of Gastroenterology, Rize, Turkey \\ ${ }^{4}$ Recep Tayyip Erdoğan University Faculty of Medicine, Department of Radiation Oncology, Rize, Turkey \\ ${ }^{5}$ Recep Tayyip Erdoğan University Faculty of Medicine, Department of Pathology, Rize, Turkey
}

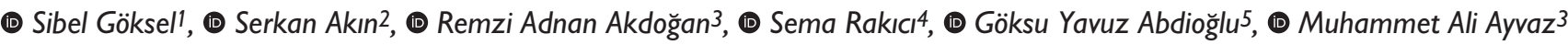

\begin{abstract}
Gastric metastasis of choriocarcinoma is rarely reported in the literature. This case report presents the case of multiple metastatic testicular choriocarcinoma mimicking gastric cancer, with melena as the initial symptom. In this case, ${ }^{18}$ fluorine-fluorodeoxyglucose positron emission tomography/computed tomography (PET/CT) showed that the testis was the primary focus. The contribution of PET/CT is significant to primary focus detection in metastatic diseases of unknown primary origin that presented gastrointestinal bleeding. In addition to its use in staging of testicular carcinoma, PET/CT provides significant benefit in evaluating patients with increased levels of tumor markers and in detecting recurrence. Keywords: Gastric metastasis, melena, testicular choriocarcinoma, ${ }^{18} \mathrm{~F}-\mathrm{FDG}$ PET/CT
\end{abstract}

\section{Öz}

Koryokarsinomun mide metastazı literatürde oldukça nadir bildirilmiştir. Bu olgu raporu, mide kanserini taklit eden, başlangıç semptomu melena olan multipl metastatik testis koryokarsinomlu bir hastayı sunmaktadır. Bu olguda, ${ }^{18 f l o r-f l o r o d e o k s i g l u k o z ~ p o z i t r o n ~ e m i s y o n ~ t o m o g r a f i s i / b i l g i s a y a r l ı ~}$ tomografi (PET/BT) testisin primer odak olduğunu gösterdi. PET/BT'nin katkısı, gastrointestinal kanama ile gelen primeri bilinmeyen metastatik hastalıkta primer odak tespitinde önemlidir. Testis kansererinde PET/BT, hastalık evrelendirilmesine sağladığı faydalara ek olarak, özellikle tümör belirteçleri artmış ve nüks hastalık açııından şüpheli olan hastalarda rekürrensi tespit etmede önemli fayda sağlar.

Anahtar kelimeler: Mide metastazı, melena, testiküler koryokarsinom, ${ }^{18} \mathrm{~F}-\mathrm{FDG}$ PET/BT

Address for Correspondence: Sibel Göksel MD, Recep Tayyip Erdoğan University Faculty of Medicine, Department of Nuclear Medicine, Rize, Turkey Phone: +90 5433897714 E-mail: sibelkandemirgoksel@gmail.com ORCID ID: orcid.org/0000-0003-1425-8347 Received: 08.01.2019 Accepted: 13.10.2020 

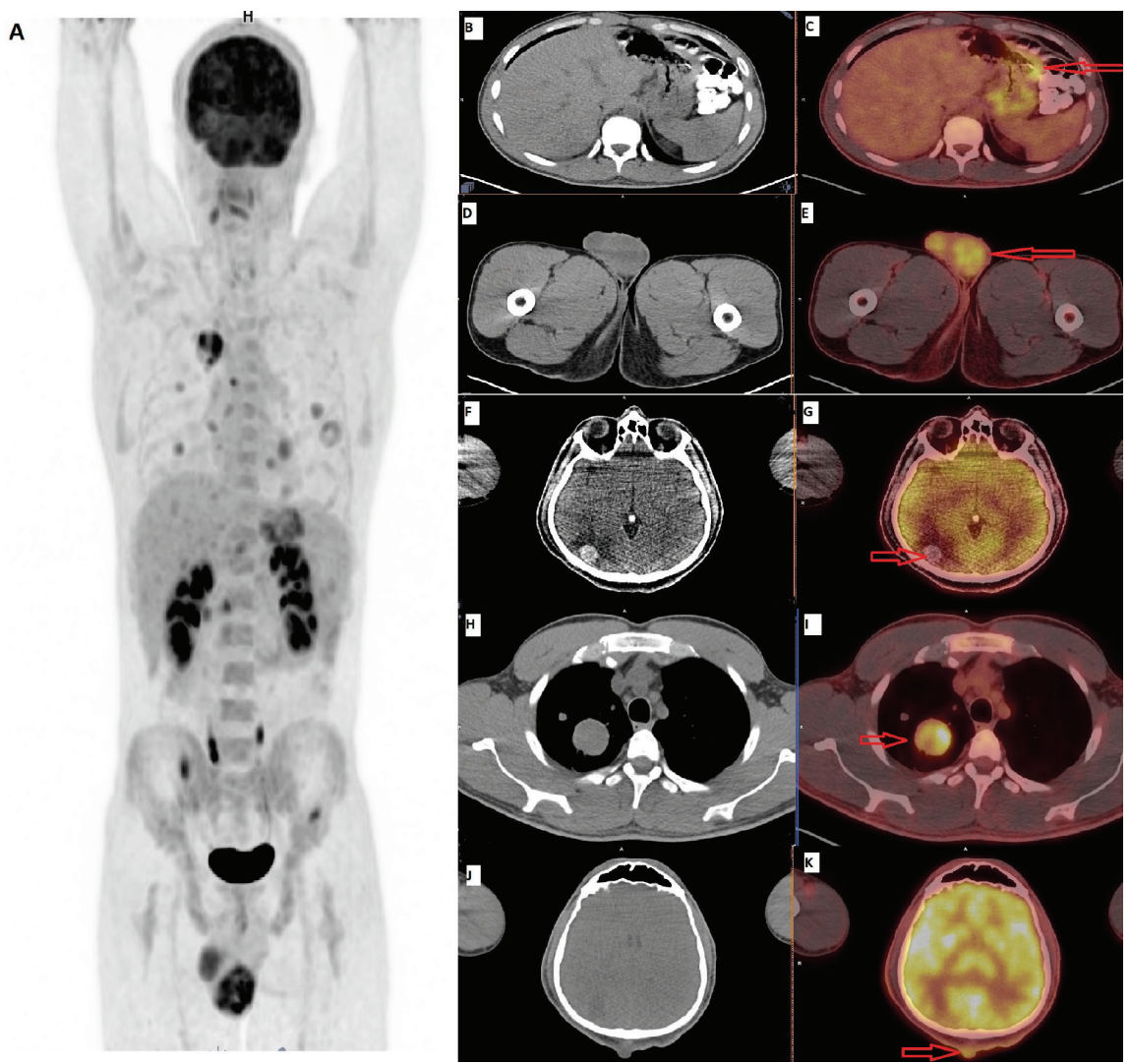

Figure 1. Testicular choriocarcinoma diagnosed with gastric metastases is extremely rare in the literature $(1,2,3,4)$. A 27-year-old male presented with anemia and melena. Polypoid ulcerated lesion on the gastric greater curvature with active bleeding was detected using gastroscopy. The patient underwent 18 fluorine-fluorodeoxyglucose (18F-FDG) positron emission tomography/computed tomography (PET/CT) for clinically suspected gastric cancer. Focal ${ }^{18 F-F D G ~ u p t a k e ~ w a s ~ f o u n d ~ o n ~ t h e ~ g a s t r i c ~ g r e a t e r ~ c u r v a t u r e ~(A, ~ B, ~ C) . ~ M e t a s t a t i c ~ g a s t r o i n t e s t i n a l ~ i n v o l v e m e n t ~ m a y ~ b e ~ s e e n ~ i n ~}$ approximately $5 \%$ of these cases $(5,6)$. Hypermetabolic focus and asymmetric growth were also found in the left testicle (D, E), and multiple metastatic disease that involves the brain $(F, G)$, lungs $(H, I)$, skin $(J, K)$, liver, lymph node, and bone was detected on PET/CT. Based on PET/CT, all metastases were thought to arise from the testicles. As in this case, in addition to the contribution of PET/CT in diagnosis of testicular cancer, it is very important imaging technique in clinical practice in staging and detection of recurrence (7).

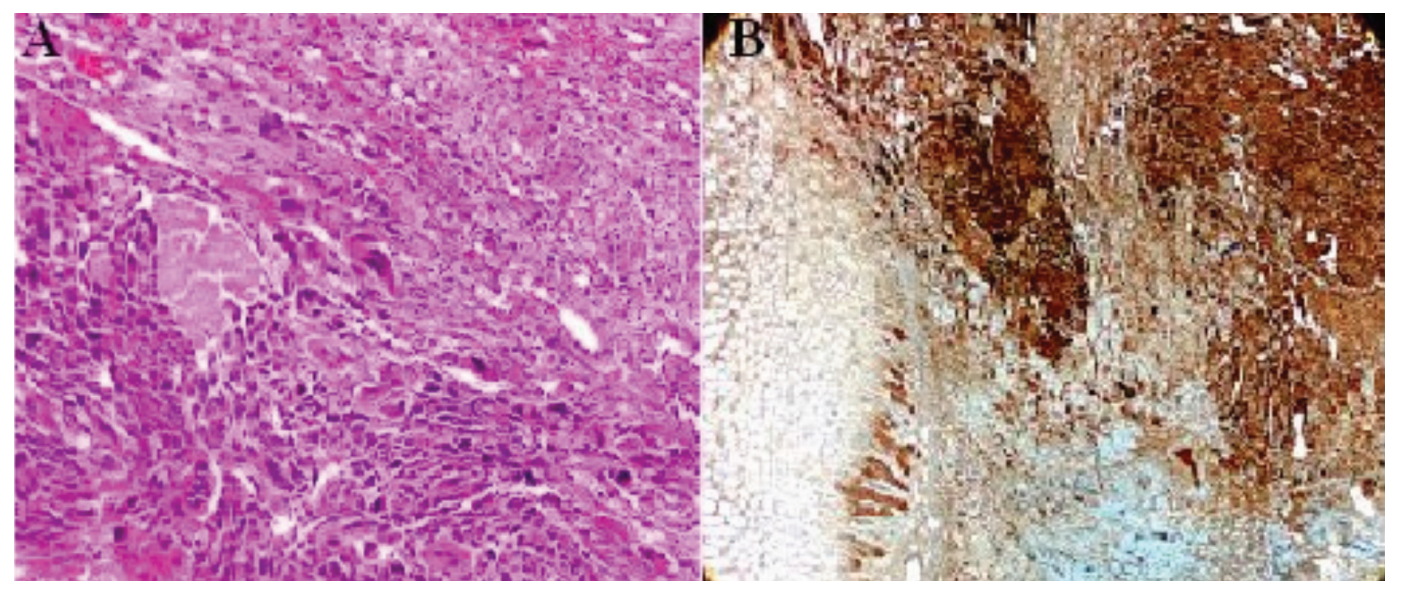

Figure 2. On immunohistochemical examination of the specimen, metastasis of testicular choriocarcinoma was detected in the gastric biopsy specimen. Pathological images of gastric biopsy material. A) Hypercromatic multinuclear and syncytiotrophoblastic cells with large eosinophilic cytoplasm (hematoxylin eosin staining, x400). B) Human chorionic gonadotropin immunohistochemical staining (x400). The germ cell malignancy in young men can present with melena, and malignancy should be suspected in patients presenting with these symptoms. 


\section{Ethics}

Informed Consent: Consent form was filled out by all participants.

Peer-review: Externally peer-reviewed.

\section{Authorship Contributions}

Surgical and Medical Practices: S.G., S.A., R.A.A., S.R., G.Y.A., M.A.A., Concept: S.G., M.A.A., Design: S.G., M.A.A., Data Collection or Processing: S.G., M.A.A., Analysis or Interpretation: S.G, R.A.A., Literature Search: S.G., Writing: S.G.

Conflict of Interest: No conflict of interest was declared by the authors.

Financial Disclosure: The authors declared that this study received no financial support.

\section{References}

1. Bosl GJ, Motzer RJ. Testicular germ-cell cancer. N Engl J Med 1997;337:242-253.

2. Harikumar $\mathrm{R}$, Harish $\mathrm{K}$, Aravindan $\mathrm{KP}$, Thomas $\mathrm{V}$. Testicular choriocarcinoma with gastric metastasis presenting as hematemesis. Indian J Gastroenterol 2004;23:223-224.

3. Aydiner A, Olgaç V, Darendeliler E, Oztürk N, Dinçol K, Erseven G, Onat $\mathrm{H}$. Testicular germ cell tumor with gastric metastasis. Acta Oncol 1993;32:459-460.

4. Shariat SF, Duchene D, Kabbani W, Mucher Z, Lotan Y. Gastrointestinal hemorrhage as first manifestation of metastatic testicular tumor. Urology 2005;66:1319.

5. Hsu CC, Chen JJ, Changchien CS. Endoscopic features of metastatic tumors in the upper gastrointestinal tract. Endoscopy 1996;28:249-253.

6. Cook GJ, Sohaib A, Huddart RA, Dearnaley DP, Horwich A, Chua S. The role of 18F-FDG PET/CT in the management of testicular cancers. Nucl Med Commun 2015;36:702-708.

7. Molina Infante J, Beceiro Pedreño I, Ripoll Noiseux $C$, Marín Jiménez I, González Asanza C, Menchén Fernández-Pacheco P. Gastrointestinal hemorrhage due to metastatic choriocarcinoma with gastric and colonic involvement. Rev Esp Enferm Dig 2004;96:77-80. 